\title{
THE ENVIRONMENTAL AND ECONOMIC SUBSTANTIATION OF INVESTMENTS IN GREEN BUILDINGS
}

\author{
Linda KAUŠKALE ${ }^{1}$, Frank RIEMENSCHNEIDER ${ }^{2}$ \\ ${ }^{1}$ Riga Technical University, Latvia \\ ${ }^{2}$ Münster University of Applied Sciences, Germany \\ Corresponding author e-mail: Linda.Kauskale@rtu.lv
}

\begin{abstract}
Investment tendencies in a country and particular region in general have a crucial role in the creation of the sustainable environment of the city, spatial planning and land use management. Green construction has great potential for investing and can provide variety of benefits for sustainable longterm development of the country. The aim of the research is to analyse the environmental and economical substantiation of investments in green buildings, with particular focus on the experience of Germany. The researchers used logical, inductive, quantitative and statistical analysis logical methods, analysis of scientific literature as well as comparative analysis. Lack of information is a peculiarity of real estate market, and especially affects the activities in green building construction, that also shows the necessity of developing economic and environmental criteria for substantiation of the decision-making process. Future research directions have been identified as well.
\end{abstract}

Keywords: Construction, energy efficiency, environment, Germany, green buildings, green building certification, investments, real estate, sustainability.

\section{INTRODUCTION}

Since economic, environmental and social factors are the guidelines of sustainable development implementation policies, more attention is being paid to these questions by all industries. Construction industry and real estate market of many countries has special influence. The decision-making on green building construction also affects the construction costs (economic aspect), affordability of green buildings (social aspect), and development of environment in general (environmental aspects).

The aim of the research is to analyse the environmental and economical substantiation of investments in green buildings, with particular focus on the experience of Germany. The tasks of the research are as follows:

- to analyse theoretical and practical aspects of environmental development and its problems as well as the influence of environmental aspects of construction on sustainable national economic development, the importance of green buildings in this process;

- to analyse current situation in real estate market and the ecological construction in Germany, including legal aspects and regulations; 
- to determine economic and environmental factors that influence the investments in green construction and to define promoting and restrictive factors of green building construction;

- to summarize the research results and to propose recommendations.

Logical, inductive, quantitative and statistical analysis, logical methods, and scientific literature analysis and comparative analysis were used in the research. The research includes integrated approach to the analysis of the environmental, economic and social factors, as well as other identified factors. The research includes international experience, but primary is focused on the experience of Germany. The research provides the analysis of theoretical background and latest studies in the field, actual practical research question, new definitions, conclusions on conducted research and future research directions.

\section{TRENDS, PROBLEMS AND CHALLENGES OF ENVIRONMENTAL DEVELOPMENT}

Nowadays real estate investors in investment decision making should take into account a variety of internal and external factors influencing entrepreneurship and the fact that the final decision-making can be influenced by variety of aspects. Because of the increasing tendency of growth of population worldwide, more construction activities are required now and will be required even more in the future.

Population growth and economic development are marked as ubiquitous drivers of environmental change with a special attention to energy, transport, urbanization and globalization (UNEP, 2012). According to previously done research (Manders et al., 2012), without new policies, by 2050, an increase of world population is expected from 7 billion to over 9 billion; the world economy is projected to nearly quadruple. The same research shows that by 2050 about $70 \%$ of the world population is projected to be urban residents that also will have significant consequences for the environment, including air pollution, transport congestion, waste management and other areas. In addition, agricultural land is projected to expand globally at diminishing rate and it is expected that in 2050 over a quarter of its population will be aged over 65 years, compared to about $15 \%$ nowadays (Manders et al., 2012). As in some regions in the world the ageing of population is observed, also the necessity and importance of agefriendly building construction will grow (Štaube et al., 2016).

As the role of construction industry increases, effective use of renewable resources becomes especially important, and according to UNEP (2016) annual report there is a positive tendency of the growth of investments in asset finance in renewable energy. Interconnection between pollution and the level of income is important as well. The Environmental Kuznets Curve (EKC) hypothesis (Kuznets, 1955) shows an inverted-U-shaped relationship between different types of pollutants and per capita income; environmental pressure increases to a certain level as income increases, but after that, it decreases, that is also described by Dinda (2004) in the research on EKC. This relationship explains the interconnection between the environmental and economic aspects in the 
development of national economy. The planning of environmental policy starts with initiative and is followed by detailed environmental program development and implementation, creation of environmental management system with the system for checking and improvement to achieve the aim, environmental testing, manuals, with the test cycle of maximum 3 years (Bahadir, Parlar, \& Spiteller, 2000).

The environmental pollution reduction concept is based on a gradual approach - systematic analysis of all the following aspects (Kḷavinš \& Zaḷoksnis, 2010):

- Preventing and elimination of the formation of pollution;

- Reduction of pollution;

- Recycling of raw materials;

- Internal recycling;

- External recycling;

- Production and processing;

- Waste management.

Construction and demolition waste has become a critical issue because of the volume of construction activity being undertaken globally, therefore construction waste disposal charging schemes have been marked in economies as one of the most effective ways of managing construction waste ( $\mathrm{Lu}$ et al., 2015). Special attention is being paid to energy issues in buildings. The amount of oil and gas capacity required to meet the demand during the next 20 years is more than twice bigger in comparison with the amount realized during the last decades (Berends, 2007). In Germany intensity of energy efficiency policy from 1980s up to now has significantly increased, especially for households group, which is important for a long-term sustainable development, as households are a big group of energy consumers (Bertoldi \& Mosconi, 2015).

The complexity of increase of green building construction for all market participants arises from the fact, that sometimes environmental, economic and social aspects are contradictory. That is the reason why the development of real estate market sustainability model and the development of motivation system of market participants through different programs and information systems can be one of the opportunities for the solution.

The concept of sustainability was first introduced in 1713 by Hans Carl von Carlowitz Freiberg, Saxonia, and the term was widely used in the field of forestry, then it was translated into English and French (Carlowitz, 1732; Lexicon der Nachhaltigkeit, 2015). The concept of "sustainable development" was first introduced in 1987 in Brundtland report (World Commission on Environment and Development, 1987).

The main environmental and economical indicators of national sustainability strategy in Germany defined by the Federal Office of Statistics (Statistisches Bundesamt) (2016) are: energy productivity, primary energy consumption, raw material productivity, greenhouse gas emissions, renewable energy, share of final energy consumption, share of electricity consumption (gross), increase in settlement and traffic area, biodiversity and landscape quality, state deficit, structural deficit, debt, ratio of gross investment to GDP, GDP per inhabitant, 
freight transport intensity, person transport intensity, proportion of rail transport in freight transport, share of inland waterway transport in freight transport, excess of nitrogen, organic farming, pollution of the air and other indicators.

The facts of the history of development of sustainable buildings in Germany are the following (Federal Institute for Building, Urban and Regional Research (BBSR), 2015):

- Ordinance of Heat Protection, 1977;

- The Sustainable development concept defined in "Brundtland Report" and United Nations Conference on Environment and Development in 1987;

- United Nations Conference on Environment and Development, also called Earth Summit, Rio de Janeiro 1992;

- Guidelines for Sustainable Buildings in Germany (Leitfaden Nachhaltiges Bauen (LFNB)) and Sustainable Building Round Table, 2001;

- Development of National Sustainability Strategy in 2002;

- Energy Saving Ordinance, 2001;

- Integrated Climate and Energy Program accepted in 2007;

- Development of the German Quality Label for Sustainable Building in cooperation with DGNB (Deutsche Gesellschaft für Nachhaltiges Bauen German Sustainable Building Council) (pilot version);

- Renewable-Energy-Heat law, the use of regenerative energy for heating/cooling of buildings in 2009;

- Introduction of the Sustainable Building Assessment System (BNB) in 2009;

- "Sustainability" implementation program of the State Secretary for Sustainable Development in 2010;

- LFNB (Leitfaden Nachhaltiges Bauen - Guidelines for Sustainable Buildings) and BNB (Bewertungssystem Nachhaltiges Bauen - Evaluation System of Sustainable Buildings) binding for federal buildings in 2011;

- Supplement to the LFNB, Part C "Recommendations for the Sustainable Use and Operation of Buildings" and Part D "Building in Existing Buildings" in 2013;

- Further development of "Sustainability" implementation program of the State Secretary for Sustainable Development in 2015;

- The following goals were defined:

- by 2020 to reduce greenhouse gas emissions by $40 \%$;

- by 2020 to build climate-neutral new buildings;

- by 2050 to reduce greenhouse gas emissions by $80 \%$ to $95 \%$;

- by 2050 to reduce primary energy demand in the building sector by $80 \%$.

The German National Action Plan on Energy Efficiency (NAPE) and German Action Programme on Climate 2020 (APC) instruments could achieve annual energy savings of 241.2 petajouls in final energy consumption and 394.2 petajouls in primary energy consumption by 2020 , leading to a reduction in greenhouse gas emissions of 24.2 metric tons of $\mathrm{CO}_{2}$ equivalent, and also NAPE and APC measures could help consumers and industry to avoid fuel costs of 90-100 billion 
Euro, to trigger additional investments of at least 70-80 billion Euro, and these investments mean that Germany's GDP grows by $0.4 \%$ to $2.6 \%$ and that approximately 48000 additional full-time-equivalent jobs are created (Ringel et al., 2016), which are big green economy support activities for the country and have high socio-economic meaning.

In energy policy implementation, special attention should be paid to a range of planning and managing problems of energy efficiency, energy issue should be solved also at district level (Actiņa, Geipele, \& Zeltiņš, 2015) and special attention should be paid to energy efficiency process management (Actina, 2015). After World War II, spatial planning and state spatial planning in Germany were revised and integrated into the national planning system; the Constitution of the Federal Republic of Germany adopted in 1949 is called the Basic Law (Grundgesetz für die Bundesrepublik Deutschland) (Deutscher Bundestag, 2014), last amended by Article 1 of the Law at 23.12.2014 and distinguishes the following categories of administration (Pahl-Weber \& Henckel, 2008, p. 26):

- direct implementation of federal laws by the Federation;

- implementation of federal legislation by the states on behalf of the Federation;

- administration with joint responsibility;

- implementation of federal legislation by the states in their own right;

- implementation of state legislation by the states.

In summer 2002, the Technical Committee of ISO (TC 59), responsible for construction, decided to start a standardization project for sustainable construction; the declaration of construction products and the building evaluation were elaborated only under the environmental aspects; in Germany the work was carried out in five different working groups (Federal Ministry for the Environment, Nature Conservation, Construction and Nuclear Safety, 2016b):

WG 1. General principles and terminology;

WG 2. Sustainability indicators;

WG 3. Environmental declarations of construction products;

WG 4. Assessment of the effects of buildings on the environment;

WG 5. Civil engineering works.

Environmental development programs and implementation of sustainability in construction management is crucial nowadays, however, it should be acceptable for all market participants also from economic and social points of view. However, the industry has a big potential of sustainable development implementation, not just in land use, spatial planning and other areas, but also in implementation of sustainability aspects in management of enterprise and construction process.

\section{GREEN BUILDINGS AND SUSTAINABILITY}

Buildings consume roughly one third of the total energy usage on the global scale, however, the following has to be noted (Huovila et al., 2007):

- The building sector has the biggest potential for delivering significant and cost-effective greenhouse gas emission reductions; 
- Countries will not meet emission reduction targets without supporting energy efficiency gains in the building sector. The building sector is the key to meeting national greenhouse gas emission reduction targets;

- Proven policies, technologies and knowledge already exist to deliver significant cuts in building related greenhouse gas emissions;

- Building industry is committed to action and in many countries is already playing a leading role;

- Significant co-benefits including employment will be created by policies that encourage energy efficient and low-emission building activity;

- Failure to encourage energy-efficiency and low-carbon when building new or retrofitting will lock countries into the disadvantages of poor performing buildings for decades.

To improve renewable energy usage, the Renewable Energy Sources Act (EEG) was developed which entered into force in 2000 and was a successful instrument in the promotion of green electricity in Germany. The aim of the Renewable Energy Sources Act was to enable the new technologies, such as wind and solar energy, to enter the market because of fixed remuneration, guaranteed acceptance and the priority of the power supply (Federal Ministry for Economic Affairs and Energy, 2014). For buildings, the German Thermal Insulation Ordinance (WSVO) came into effect in 1977, determined the measures by which the heat loss was minimized and since 2009, all buildings (residential and nonresidential) need an energy certificate when they are rented, sold or leased (Krolkiewicz, 2016). This is also an opportunity for buyers, investors and future tenants to visually obtain an overview of the energy quality of a property (Krolkiewicz, 2016).

German scientist Ernst Haeckel (1834-1919) in Generelle Morphologie der Organismen (Haeckel, 1866) was the first to use the term "ecology" ("Ökologie") in 1866, as describen in Roy Choudhury (2015)

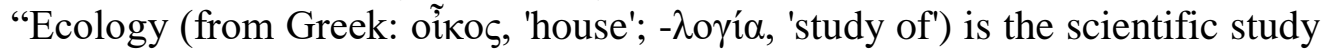
of biological interactions among organisms and their environment, such as the interactions organisms have with each other and with their abiotic (non-living) environment. Ancient Greek philosophers such as Hippocrates and Aristotle laid the foundations of ecology in their studies on natural history. Modern ecology transformed into a more rigorous science in the late $19^{\text {th }}$ century. Evolutionary concepts on adaptation and natural selection became cornerstones of modern ecological theory" (Roy Choudhury, 2015). Ecological building also referred to as "green building" internationally, transfers the concept of sustainability into the construction sector: buildings are to be created and operated in such a way that will also leave a life-like and intact environment to the future generations. Numerous certain features fall under the aspect of ecological construction: solar technology, thermal insulation, natural building materials, natural floor coverings or natural colours are just a few examples (O`Daniel, 2012).

On basis of Building Research Establishment Environmental Assessment Method (BREEAM), Leadership in Energy and Environmental Design (LEED), and Deutsche Gesellschaft für Nachhaltiges Bauen (DGNB - German Sustainable Building Council) methodologies of green building evaluation standards (BRE 
Global Ltd., 2009; DGNB System, 2014; USGBC, 2014), the authors summarize, that the concept of green building includes management, waste, health and wellbeing, pollution, energy, atmosphere, land use and ecology, transport, materials and resources, water and its efficiency, innovation, location and transportation, indoor environmental quality, and other components, as well as environmental, economic, technical processes and site quality, and promotes development of sustainable cities and planning systems. The concept of sustainable buildings is wider than the concept of green building (HFK Rechtsanwälte Heiermann Franke Knipp, 2009). However, it is hard to draw the borders of the concept of sustainability. Three dimensions of sustainable buildings are shown in Table 1.

Table 1. Three Dimensions of Sustainable Buildings (Sustainable Building Information Portal of Federal Ministry for the Environment of German Federation, 2016) [Table made by authors]

\begin{tabular}{|c|c|c|}
\hline Economic considerations & Ecological considerations & Social and cultural dimension \\
\hline $\begin{array}{l}\text { The following Life Cycle } \\
\text { Costs (LCC) are considered: } \\
\text { Construction costs: } \\
\text { Land planning costs } \\
\text { (including development } \\
\text { costs), buildings (including } \\
\text { construction site operating } \\
\text { costs), construction } \\
\text { supervision and } \\
\text { documentation costs, } \\
\text { brokerage costs, notary costs, } \\
\text { insurance costs during the } \\
\text { construction period, etc. } \\
\text { Usage costs: } \\
\text { - Environmental } \\
\text { consumption: } \\
\text { heating, hot water, lighting } \\
\text { (electricity), water, } \\
\text { sewage; } \\
\text { - Building and component- } \\
\text { specific expenses: } \\
\text { cleaning, maintenance and } \\
\text { repair, modernization. } \\
\text { Dismantling costs: } \\
\text { Demolition, removal, reuse or } \\
\text { recycling, disposal. }\end{array}$ & $\begin{array}{l}\text { Quantifiable indicators for the } \\
\text { ecological building assessment } \\
\text { are identified nationally and } \\
\text { internationally: } \\
\text { - Land use; } \\
\text { - Primary energy expenditure } \\
\text { (renewable / non- } \\
\text { renewable); } \\
\text { - Greenhouse potential } \\
\text { (GWP), with regard to } \\
\text { "global warming"; } \\
\text { - Ozone depletion potential } \\
\text { (ODP), with respect to the } \\
\text { "ozone hole"; } \\
\text { - Acidification potential } \\
\text { (AP), with regard to the } \\
\text { "acid rains"; } \\
\text { - Eutrophication potential } \\
\text { (EP), with regard to water } \\
\text { or ground water; } \\
\text { - Photochemical ozone } \\
\text { creation potential (POCP), } \\
\text { with regard to the "summer } \\
\text { smog". }\end{array}$ & $\begin{array}{l}\text { By optimizing building design, } \\
\text { material selection, building } \\
\text { construction and plant } \\
\text { engineering, these aspects can } \\
\text { be achieved already in the } \\
\text { planning phase. } \\
\text { Within the social and cultural } \\
\text { dimension of sustainability, } \\
\text { protection objectives are } \\
\text { defined in the following areas: } \\
\text { Design, aesthetics; } \\
\text { Accessibility; } \\
\text { Health and comfort, which } \\
\text { includes: } \\
\text { - thermal comfort (room } \\
\text { temperature, room air } \\
\text { humidity); } \\
\text { - the hygienic comfort (room } \\
\text { air quality, air movement); } \\
\text { - acoustic comfort (building } \\
\text { acoustics, noise emissions); } \\
\text { - optical and visual comfort } \\
\text { (lighting). }\end{array}$ \\
\hline
\end{tabular}

The endeavour to make the ecological quality of a building measurable led to the method of life cycle assessment, which was essentially divided into three steps (Donath, Fischer, \& Hauke, 2011):

Step 1 - Balance sheet;

Step 2 - Impact assessment;

Step 3 - Sensitivity analysis. 
Besides ecological, economical and socio-cultural aspects of sustainability, special attention is being paid also to technical quality, process quality and location features (Federal Ministry for the Environment, Nature Conservation, Construction and Nuclear Safety, 2013). Social sustainability aspect in buildings is important as well. The concept of social sustainability has been under-theorised or unfortunately often oversimplified in existing theoretical studies, and there have been just a few attempts to define social sustainability as an independent dimension of sustainable development (Colantonio, 2008).

Sustainability aspects are important at all levels and in all phases of life cycle, and, for instance, achievement of macro-economical stability can also promote attracting of investments, especially in the area of real estate operation. Previous studies also approach macroeconomic problems and a number of related issues that may be useful in the management of companies in the construction industry and real estate market (Kauškale \& Geipele, 2015). According to several studies PESTEL factors are of great importance as well (Štaube, 2013; Grizāns, 2015). According to the conducted literature analysis, the authors propose the following definitions of real estate object sustainability, sustainable real estate object management and macroeconomic sustainability:

Real Estate Object Sustainability is sustainability of economic, social, environmental and technological factors as a joint system; quality of all processes, including building materials and technologies; well-considered internal and external environment; optimal use of resources that reflects in costs and energy use patterns during all life cycles of building;

Sustainable Real Estate Object Management is systematic planning, organization, motivation, control and coordination of all internal and external sustainability influencing factors and processes in the real estate object at all management levels;

Macroeconomic Sustainability is long-term sustainable development of all sectors of national economy, which is reflected in stable macroeconomic and monetary development indicators and growth rates.

Important aspect is affordability and financing of ecological and environmentally friendly construction activities. KfW Group offers a number of ways of financing offered by the following programs (KfW Group, 2016a):

- Energy-efficient building and renovation in the company (Energieeffizient Bauen und Sanieren im Unternehmen);

- Energy-efficient waste heat utilization (Energieeffiziente Abwärmenutzung);

- Renewable energy storage (Erneubare Energien - Speicher);

- Renewable energies - premium deep geothermal energy (Erneubare Energien - Premium - Tiefengeothermie);

- Reconstruction Bank - Environmental program (KfW Umweltprogramm);

- Reconstruction bank - Consortium Credit Energy and Environment (KfWKonsortialkredit Energie und Umwelt);

- Energy efficiency in production (Energieeffizienz in der Produktion);

- Renewable energy - Standard (Erneubare Energie - Standard);

- Renewable Energy - Premium (Erneubare Energie - Premium); 
- Offshore - wind energy (Offshore - Windenergie);

- BMUB - Environmental Innovation Program (BMUB - Umweltinnovationsprogramm).

Since 1948, when KfW Group was founded and according to its statutory mission, KfW has been supporting change and encouraging the mentioned ideas and programs in Germany, Europe and throughout the world for more than 65 years and to achieve these aims has provided nearly one trillion Euro in loans (KfW Group, 2016b). European Union Investment Bank (European Union, 2016) provides funding for projects that help to achieve EU aims, within and outside the EU and was founded in 1958 and its president is Werner Hoyer. The first Green Bank in the United States was established in 2009, following the ideas of environmental protection, including the conversion plans for building future headquarters with a zero energy balance, meeting energy needs with low-cost, geographically accessible, and renewable energy sources (Ganbat, Popova, \& Potravnyy, 2016). Nominal Euro area interest rates currently are now at historically low level, with the interest rate on the main refinancing operations about $0 \%$, but very low interest rates are partly the choice of the central bank, as it is also an influence of global and euro area-specific factors, some of them are of a long-term, others are associated with the legacy of financial crisis (European Central Bank, 2015). Affordable interest rates can give additional opportunities for financing green buildings. Green building development tendencies are analysed in the next Section.

\section{TRENDS, PROBLEMS AND CHALLENGES OF ENVIRONMENTAL DEVELOPMENT}

Construction industry faces a number of external and internal risks. For example, large projects in Germany, such as Elbphilharmonie, Stuttgart 21, the new Berlin-Brandenburg International Airport, Cologne Opera, or other projects, cost significantly more and construction period is longer than previously announced, and, as a result, public authorities are not able to strictly control the cost and timeframe of these construction projects - in the case of 300 examined federal building projects (with individual costs between 10 and 240 million Euro in the years of completion from 2000 to 2015), almost $60 \%$ of the projects were included in the cost frame, taking into account the increase of price (Federal Ministry for the Environment, Nature Conservation, Construction and Nuclear Safety, 2016a).

The peculiarity of cyclical real estate market development influences the investments in green buildings as well; in the period of recession and crisis inhabitants receive less income, purchasing power reduces, companies do not have financial resources, and investments in green buildings reduce, if they are more expensive. Green buildings may be expensive in the beginning, but during the life cycle can pay off.

The countries with the biggest number of green building profiles are the United States, Great Britain, Canada, China and Australia (GBIG, 2016a). The German Sustainable Building Council (DGNB - Deutsche Gesellschaft für 
Nachhaltiges Bauen) was founded in 2007 by 16 initiators from various subject areas within real-estate and construction sectors with the aim to promote sustainable and economically efficient building more strongly in future (DGNB, 2016a). All green building certification systems include environmental and economic indicators. In DGNB system attention is paid also to the examination of life cycle assessment of a building or urban district, as well as location preferences. DGNB Certified Buildings in Germany by categories and DGNB certificates for new offices and administrative buildings are shown in Fig. 1.

a)

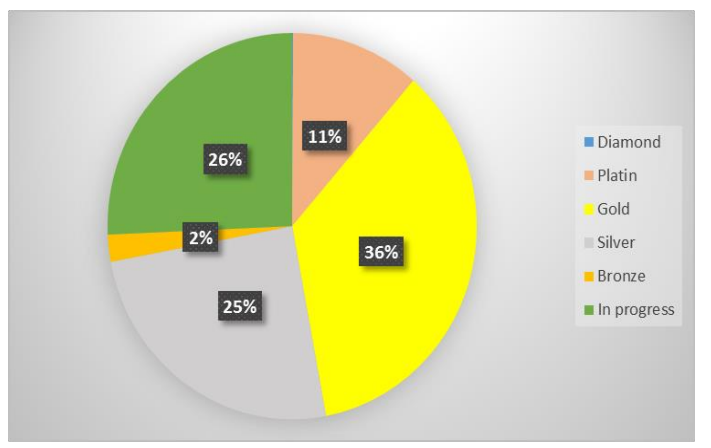

b)

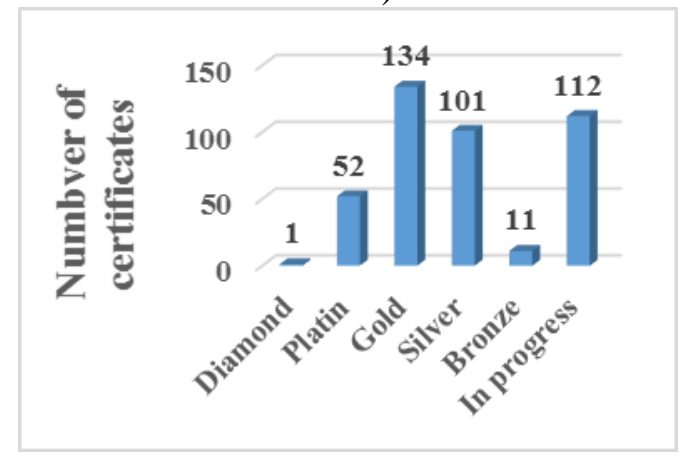

Fig. 1. a) DGNB Certified Buildings in Germany by categories; b) DGNB certificates for new office and administrative buildings (DGNB System, 2016b) as of 13.10.2016. [Figure made by authors].

Fig. 1b) shows high demand for certification of office and administrative buildings in Germany in comparison to other types of buildings. DGNB Certifications in the world are shown in Fig. 2.

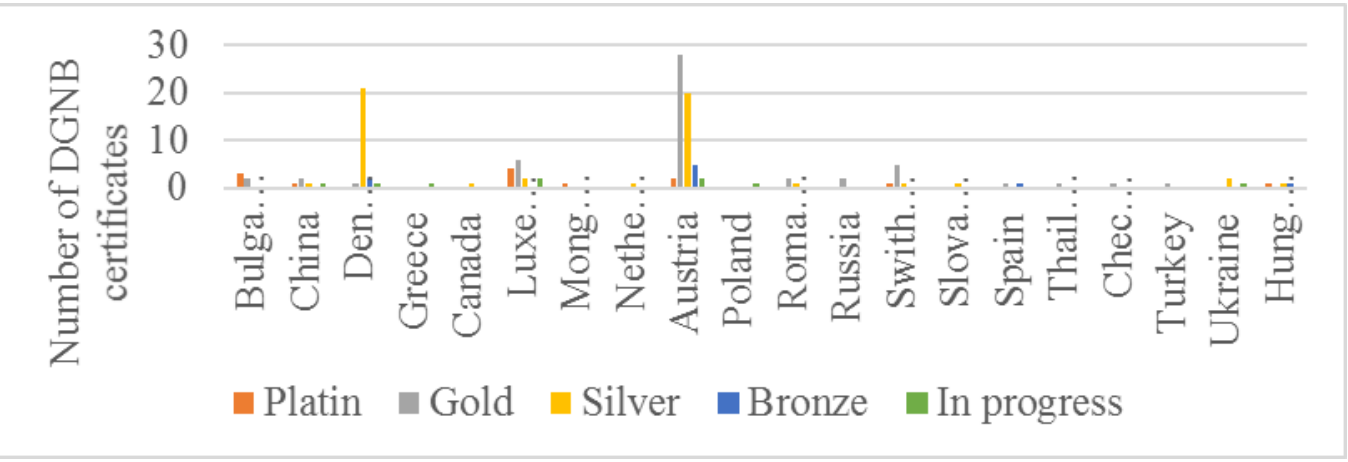

Fig. 2. DGNB Certification in the World (DGNB System, 2016b) [Figure made by authors].

According to the USGBC nearly 172000 gross floor space in square metres (GSM) is certified daily according to the LEED standard, and currently more than 69800 commercial and institutional projects, which stand at 1.23 billion GSM in area, are to participate in the ecological building classification system (Baulinks, 
2015). By the amount of LEED certified buildings Germany has the $6^{\text {th }}$ place which is shown in Table 2.

Table 2. Ranking of countries by the amount of LEED certified buildings as of 22.7.2015. (Baulinks, 2015).

\begin{tabular}{|c|l|c|c|c|}
\hline Rank & Nation & $\begin{array}{c}\text { LEED-certified } \\
\text { area } \\
\text { in GSM (million) }\end{array}$ & $\begin{array}{c}\text { Total of LEED-certified } \\
\text { and registered area in } \\
\text { GSM (million) }\end{array}$ & $\begin{array}{c}\text { Total number of } \\
\text { LEED-certified } \\
\text { registered products }\end{array}$ \\
\hline 1 & Canada & 26,63 & 63,31 & 4.814 \\
\hline 2 & China & 21,97 & 118,34 & 2.022 \\
\hline 3 & India & 13,24 & 73,51 & 1.883 \\
\hline 4 & Brasil & 5,22 & 24,50 & 991 \\
\hline 5 & South Korea & 4,81 & 17,47 & 279 \\
\hline 6 & Germany & 4,01 & 8,42 & 431 \\
\hline 7 & Taiwan & 3,84 & 9,08 & 149 \\
\hline 8 & UAE & 3,13 & 53,44 & 470 \\
\hline 9 & Turkey & 2,95 & 23,74 & 197 \\
\hline 10 & Sweden & 2,54 & 4,20 & 53.908 \\
\hline-- & USA & 276,90 & 727,34 & \\
\hline
\end{tabular}

The BREEAM audit activities are conducted in two stages (Stage 1 and Stage 2), and are based on the requirements of International Standard BS EN ISO 14001:2004 Environmental Management Systems - specification with guidance for use provides ongoing independent, third party audit and certification of environmental management systems (GreenBookLive. BRE Group, 2015). Energy conservation in the sector of real estate is claimed to possess significant possibilities also for climate mitigation actions (Christersson, Vimpari, \& Junnila, 2015). Typical energy analysis users are architectural groups (designers, architects, master planners, urban designers, interior designers), green consultants (BREEAM, LEED, DGNB, Estidama, other "green" rating systems), engineers (HVAC, mechanical, electrical, Building Physics) and other market participants (Beržanskis, 2015).

Real estate prices are driven by local economic growth variables; and from an investment perspective, real estate prices follow anticipated growth prospects of an urban economy (Coulson, Liu, \& Villupuram, 2013). Systematic evaluation of land use efficiency is necessary in order to support and improve the decisionmaking in land-use management area and to promote land use in better and more efficient way (Auziņšs, Geipele, \& Stāmure, 2013).

Urban areas should be sustainable as well. Increasingly, urban green space is seen as an integral part of cities providing a range of services to both people and wildlife in urban areas (James et al., 2009).

Facility management is an important aspect for investors as well and its optimization and improvements can result in cost reduction. The comparison of corporate real estate management and facility management is shown in Table 3. 
Table 3. Comparison of CREM and FM (Pfnür, 2002, p. 62)

\begin{tabular}{|c|c|c|}
\hline $\begin{array}{c}\text { Comparative } \\
\text { criterion } \\
\text { The main objective }\end{array}$ & $\begin{array}{l}\text { Corporate Real Estate } \\
\text { Management (CREM) } \\
\text { Effective resource management of } \\
\text { the company orientated to its } \\
\text { individual goals }\end{array}$ & $\begin{array}{l}\text { Facility Management (FM) } \\
\text { Optimization of resources } \\
\text { orientated to the property as well as } \\
\text { their anonymous users }\end{array}$ \\
\hline $\begin{array}{l}\text { Basic disciplinary } \\
\text { orientation }\end{array}$ & $\begin{array}{l}\text { Operational: } \\
- \text { Financial } \\
- \text { Strategic }\end{array}$ & $\begin{array}{l}\text { Technology-oriented: } \\
\text { - Engineering } \\
\text { - Architectural }\end{array}$ \\
\hline $\begin{array}{l}\text { Relevant object } \\
\text { area } \\
\text { Examples of } \\
\text { typically processed } \\
\text { (elaborated) topics }\end{array}$ & $\begin{array}{l}\text { Operational property assets of } \\
\text { non-property companies } \\
\text { - Adaptation of the real estate } \\
\text { strategy to the company's } \\
\text { strategy } \\
\text { - Planning of the surface } \\
\text { requirements } \\
\text { Balance sheet and financial } \\
\text { effects } \\
\text { Real estate marketing } \\
\text { - Risk analysis } \\
\text { - Project development } \\
\text { - Location analysis }\end{array}$ & $\begin{array}{l}\text { All commercial properties, partly } \\
\text { also living spaces } \\
\text { - Building management } \\
\text { - Organization, planning and } \\
\quad \text { control of the building services } \\
\quad \text { (cleaning, mail, gatekeeper, etc.) } \\
\text { - Energy management } \\
\text { - Maintenance of buildings } \\
\text { - Building Information } \\
\text { - System } \\
\text { - Cost management } \\
\text { - Restoration }\end{array}$ \\
\hline
\end{tabular}

Not just life cycle improvements can be a substantiation of investments in green buildings, but also fiscal and monetary policy, and investment climate in general influence volumes of investments, and volumes of investments in green buildings. Promoting and restrictive factors of green building investments are shown in Table 4.

The authors define economical substantiation of investments to green buildings as follows:

- Cost improvements in maintenance period;

- Cost improvements in facility management process;

- Competitive advantage for customers and marketing opportunities;

- Qualitative projects require renovation/reconstruction activities later;

- Better conditions for financing in particular cases (support from EU funds and/government/special programs in banks, for example, KfW Group programs in Germany);

- Higher rent/lease prices and other reasons.

Ecological substantiation is defined as follows:

- More efficient use of materials and resources, implementation of energy efficiency measures;

- Higher quality of life, health and environmental aspects;

- Reduction of $\mathrm{CO}_{2}$ emissions;

- Implementation of responsible sustainable investment strategy;

- Participation in development of sustainable environment and sustainable cities and other reasons.

According to the World Green Building Council, green buildings can also have the following advantages (World Green Building Council, 2013): 
- Design and construction costs (examples of UK of cost overcome);

- Asset value;

- Operating costs;

- Workplace productivity and health;

- Risk mitigation.

Detailed description of advantages for different market participants was analysed and described by DGNB and can be found in Appendix 1.

Table 4. Promoting and restrictive factors of green building investments [developed by authors]

\begin{tabular}{|c|c|}
\hline Promoting/motivating & Restrictive/obstructive \\
\hline $\begin{array}{l}\text { - Access to financing, regulations, mortgage rates } \\
\text { - Good financial health opportunities, free assets } \\
\text { - Market pressure to find innovative opportunities } \\
\text { - Change in thinking paradigm of the buyers, } \\
\text { focus on sustainability. Available purchase price } \\
\text { of the resources } \\
\text { - Good overall economic situation in the country, } \\
\text { economic upturn, contributing to an increase in } \\
\text { demand } \\
\text { - Favourable industry development trends } \\
\text { - Competition in the industry, and hence the need } \\
\text { for the construction of the competitive real estate } \\
\text { object } \\
\text { - National development policy of green } \\
\text { construction promotion } \\
\text { - Successful investment attraction programs } \\
\text { - Good ease of doing business index (Ease of } \\
\text { doing business index is a World Bank developed } \\
\text { and calculated index that ranks } 183 \text { countries } \\
\text { according to ease of doing business in particular } \\
\text { country) }\end{array}$ & $\begin{array}{l}\text { - Lack of credit financing opportunities } \\
\text { - Limited financial opportunities, lack of } \\
\text { free funds } \\
\text { - Lack of motivation } \\
\text { - Lack of information } \\
\text { - Lack of professional skills and } \\
\text { professional employees } \\
\text { - Lack of experience in green } \\
\text { construction projects } \\
\text { - Lack of management experience } \\
\text { - Increase in the prices of resources } \\
\text { - Economic recession, crisis, contributing } \\
\text { to a reduction in demand } \\
\text { - Underdeveloped business environment } \\
\text { - Increase in object selling price, which } \\
\text { would reduce the potential number of } \\
\text { buyers } \\
\text { - Lack of long-term policies in the field } \\
\text { of green construction } \\
\text { - Competition in the industry } \\
\text { - Low ease of doing business index } \\
\text { - Difficulties to start operation }\end{array}$ \\
\hline
\end{tabular}

Green thinking and concepts of sustainability should be promoted at all levels and should be adapted to daily life as well. Research results show both the advantages and necessity of green building construction activities, but at the same time they show difficulties, connected with this issue, as big amount of information, knowledge, practical experience and financial resources are required in the beginning. But, as construction objects have a long life-cycle, the implementation of sustainability concept in this area is especially important.

\section{CONCLUSION}

The solution of the ecological issues nowadays is one of the most important guideline in national and global development. Environmental issues should be 
addressed at all levels, and they are associated with many problems and related to all areas of the economy. Construction and property market development has a direct impact on the environment in variety of aspects, today it is particularly important to address the related issues and problems in an integrated approach not only ecological, economic and social, but also in technological, political and legal aspects (all PESTEL factors). It is also very important not just for the development of environment and society, but also for private companies and investors.

Investments in green buildings can be a significant competitive advantage and sustainable investment opportunity as well. In the process of attracting green building investments activities of all market participants are important government, business sectors and households. Special attention should be paid not only to the investment climate in general, but also to the economic and environmental side of the particular investment and motivation of market participants.

The research results show, that future-oriented planning is necessary in the field of green buildings, and, at the same time, management science is highly important in the implementation of sustainability issues and in managing best performance of employees to achieve all aims and tasks to build and to maintain green buildings for the aim of sustainable development. Future research direction is further study on the development of models and application of qualitative research methods.

\section{ACKNOWLEDGMENT}

This work was done within the Deutsche Bundesstiftung Umwelt DBU (German Federal Environmental Foundation) MOE-Austauschstipendienprogramm. The Deutsche Bundesstiftung Umwelt DBU is one of Europe's largest foundations that promotes innovative and exemplary environmental projects.

\section{REFERENCES}

Actina, G. (2015). Development of Management System of Energy Efficient Processes in Latvia (Doctoral thesis, Riga Technical University). Riga: RTU Press. 234 p.

Actiņa, G., Geipele, I., \& Zeltiņš, N. (2015). Planning and managing problems of energy and energy efficiency at regional and district level in Latvia: Case study. In International Conference on Industrial Engineering and Operations Management (IEOM), (pp. 1-7). https://doi.org/10.1109/IEOM.2015.7093843

Auziņš, A., Geipele, I., \& Stāmure, I. (2013). Measuring Land-Use Efficiency in Land Management. Advanced Materials Research, 804, 205-210. https://doi.org/10.4028/www.scientific.net/AMR.804.205

Bahadir, M., Parlar, H., \& Spiteller, M. (Eds.). (2000). Springer-Umweltlexikon ( $2^{\text {nd }}$ ed.). Berlin Heidelberg New York: Springer-Verlag. ISBN 3-540-63561-0. p. 1455. https://doi.org/10.1007/978-3-642-56998-2

Baulinks. (2015). Top-10-Länder bei LEED-Zertifizierungen: Deutschland an sechster Stelle [Top 10 countries with LEED certificates - Germany on $6^{\text {th }}$ place]. Retrieved from http://www.baulinks.de/webplugin/2015/1297.php4 
Berends, K. (2007). Engineering and construction projects for oil and gas processing facilities: Contracting, uncertainty and the economics of information. Energy Policy, 35(8), 4260-4270. https://doi.org/10.1016/j.enpol.2007.02.027

Bertoldi, P., \& Mosconi, R. (2015). The impact of energy efficiency policies on energy consumption in the EU Member States: a new approach based on Energy Policy indicators. Science for Policy report by the Joint Research Centre, the European Commission's in-house science service. https://doi.org/10.2790/312804

Beržanskis, E. (2015). Equitable projects processes are the foundation to success. Retrieved from http://ibimsolutions.lt/articles/building-performance-analysis-seminar/?lang=en

BRE Global Ltd., Bream Europe Commercial (2009). BREEAM Europe Commercial 2009 Assessor Manual. Retrieved from http://www.breeam.com/filelibrary/Technical\%20Manuals/ BREEAM_Europe_Commercial_2009.pdf

Bundesinstitut für Bau-, Stadt- und Raumforschung (BBSR) (Federal Institute for Building, Urban and Regional Research of Germany) (2015). Meilensteine der Nachhaltigkeit [Milestones of Sustainability]. As cited in Bundesministerium für Umwelt, Naturschutz, Bau und Reaktorsicherheit [Federal Ministry for the Environment, Nature Conservation, Construction and Nuclear Safety, German Federation (BMUB)]. (2016a). Leitfaden Nachhaltiges Bauen. Zukunftsfähiges Planen, Bauen und Betreiben von Gebäuden [Reform Federal Building. Better cost, deadline and quality assurance for federal buildings.]. In H.-D. Hegner (Ed.). Retrieved from http://www.bmub.bund.de/fileadmin/Daten_BMU/Pools/Broschueren/nachhaltiges_ bauen_leitfaden_broschuere_bf.pdf

Bundesministerium für Ernähung und Landswirtschaft [Federal Ministry of Food and Agriculture]. (2016). Ökologischer Landbau in Deutschland [Ecological Agriculture in Deutschland]. Retrieved from http://www.bmel.de/SharedDocs/Downloads/Landwirtschaft/Oekologischer Landbau/OekolandbauDeutschland.pdf?__blob=publicationFile

Bundesministerium für Umwelt, Naturschutz, Bau und Reaktorsicherheit [Federal Ministry for the Environment, Nature Conservation, Construction and Nuclear Safety, German Federation (BMUB)]. (2013). BNB Bewertungsmethodik [BNB valuation methodology]. Retrieved from https://www.bnb-nachhaltigesbauen.de/bewertungssystem/bnb-bewertungsmethodik.html

Bundesministerium für Umwelt, Naturschutz, Bau und Reaktorsicherheit [Federal Ministry for the Environment, Nature Conservation, Construction and Nuclear Safety, German Federation (BMUB)]. (2016a). Leitfaden Nachhaltiges Bauen. Zukunftsfähiges Planen, Bauen und Betreiben von Gebäuden [Reform Federal Building. Better cost, deadline and quality assurance for federal buildings.]. In H.-D. Hegner (Ed.). Retrieved from http://www.bmub.bund.de/fileadmin/Daten_BMU/Pools/Broschueren/nachhaltiges_bauen_leitf aden_broschuere_bf.pdf

Bundesministerium für Umwelt, Naturschutz, Bau und Reaktorsicherheit [Federal Ministry for the Environment, Nature Conservation, Construction and Nuclear Safety, German Federation (BMUB)]. (2016b). Normung ISO TC 59 SC 17 [Standardization ISO TC 59 SC 17]. Retrieved from http://www.nachhaltigesbauen.de/normung-zur-nachhaltigkeit-im-+bauwesen/uebersichtzu-normungsgremien/arbeitsgruppen-des-isotc59sc17.html

Bundesministerium für Wirtschaft und Energie [Federal Ministry for Economic Affairs and Energy, German Federation]. (2014). Erneuerbare-Energien-Gesetz 2014 [The Law of Renewable Energy 2014]. Retrieved from https://www.bmwi.de/DE/Themen/Energie/Erneuerbare-Energien/eeg-2014.html

Carlowitz, H. C. (1732). Sylvicultura Oeconomica. Hausswirthliche Nachricht und Naturmäßige Anweisung zur Wilden Baum-Zucht [Housekeeping Message and Natural Instruction to Wild Tree Breedin]. (2 $2^{\text {nd }}$ ed.). Germany: Verlag Kessel. Retrieved from http://www.forstbuch.de/CarlowitzLeseprobe.pdf

Christersson, M., Vimpari, J., \& Junnila, S. (2015). Assessment of financial potential of real estate energy efficiency investments-A discounted cash flow approach. Sustainable Cities and Society, 18, 66-73. https://doi.org/10.1016/j.scs.2015.06.002

Colantonio, A. (2008). Traditional and Emerging Prospects in Social Sustainability. Measuring Social Sustainability: Best Practice from Urban Renewal in the EU 2008/02: EIBURS Working 
Paper Series. Retrieved from http://oisd.brookes.ac.uk/sustainable_communities/resources/ SocialSustainabilityProspectspaper.pdf

Coulson, N. E., Liu, C. H., \& Villupuram, S. V. (2013). Urban economic base as a catalyst for movements in real estate prices. Regional Science and Urban Economics, 43, 1023-1040. https://doi.org/10.1016/j.regsciurbeco.2013.09.012

Deutscher Bundestag (2014). Grundgesetz für die Bundesrepublik Deutschland [Basic Law of German Federation]. Retrieved from https://www.bundestag.de/grundgesetz

DGNB System (2014). DGNB Criteria. Retrieved from http://www.dgnb-system.de/en/system/criteria/core14/

DGNB System (2016a) Overview of the DGNB. Retrieved from http://www.dgnb.de/dgnbev/en/council/dgnb/index.php

DGNB System (2016b). DGNB Pre-certified and Certified Objects. Retrieved from http://www.dgnb-system.de/en/projects/

DGNB System (2016c). Benefits for all. Retrieved from http://www.dgnb-system.de/en/certification/benefits/

Dinda, S. (2014). Environmental Kuznets Curve Hypothesis: A Survey. Ecological Economics, 49(4), 431-455. https://doi.org/10.1016/j.ecolecon.2004.02.011

Donath, C., Fischer, D., \& Hauke, B. (2011). Nachhaltige Gebäude - Planen, Bauen, Betreiben [Sustainable Building Guide. Future-oriented planning, construction and operation of buildings]. Bauforumstahl. Nr. B 105. Retrieved from https://www.bauforumstahl.de/upload/ publications/Nachhaltige_Gebaeude_240113\%281\%29.pdf

European Central Bank. (2015). Annual report 2015. Retrieved from https://www.ecb.europa.eu/pub/pdf/annrep/ar2015en.pdf

European Union. European Investment Bank (EIB). (2016). Retrieved from https://europa.eu/european-union/about-eu/institutions-bodies/european-investment-bank_en

Ganbat, K., Popova, I., \& Potravnyy, I. (2016). Impact Investment of Project Financing: Opportunity for Banks to Participate in Supporting Green Economy. Baltic Journal of Real Estate Economics and Construction Management, 4, 69-83. https://doi.org/10.1515/bjreecm$\underline{2016-0006}$

GBIG (Green Building Information Gateway). (2016a). Places. Retrieved from http://www.gbig.org/places/

GreenBookLive. BRE Group. (2015). ISO 14001 Environmental Management System Certification. Retrieved from http://www.greenbooklive.com/search/scheme.jsp?id=122

Grizāns, J. (2015). Competitiveness of the Business Environment in Latvian Urban Areas and Applicable Tools for its Improvement (Doctoral thesis, Riga Technical University). Riga: RTU Press, $149 \mathrm{p}$.

Haeckel, E. (1866). Generelle Morphologie der Organismen. Retrieved from http://darwinonline.org.uk/converted/pdf/1866_Haeckel_A959.1.pdf

HFK Rechtsanwälte Heiermann Franke Knipp. (2009). Green building / Nachhaltiges Bauen. Berlin: Holga Wende. Retrieved from http://www.hfk.de/w/files/hfk-kompakt/green_building_web.pdf

Huovila, P., Ala-Juusela, M., Melchert, L., \& Pouffary, S. (2007). Buildings and climate change. Status, Challenges and Opportunities. Paris: United Nations Environment Programme. Retrieved from http://www.unep.fr/shared/publications/pdf/dtix0916xpa-buildingsclimate.pdf

Informationsportal Nachhaltiges Bauen des BMUB (Bundesministerium für Umwelt, Naturschutz, Bau und Reaktorsicherheit) [Sustainable Building Information Portal of Federal Ministry for the Environment, Nature Conservation, Construction and Nuclear Safety, German Federation (BMUB)]. (2016). Drei Dimensionen des Nachhaltigen Bauens [Three Dimensions of Sustainable Buildings]. Retrieved from http://www.nachhaltigesbauen.de/nachhaltigesbauen/nachhaltiges-bauen/drei-dimensionen-des-nachhaltigen-bauens.html

James, P., Tzoulas, K., Adams, M. D., Barber, A., Box, J., Breuste, J., Elmqvist, T., Frith, M., Gordon, C., Greening, K. L., Handley, J., Haworth, S., Kazmierczak, A. E., Johnston, M., Korpela, K., Moretti, M., Niemela, J., Pauleit, S., Roe, M. H., Sadler, J. P., \& Ward Thompson, C. (2009). Towards an integrated understanding of green space in the European built environment. Urban Forestry \& Urban Greening, 8(2), 65-75. 
https://doi.org/10.1016/j.ufug.2009.02.001

Kauškale, L., Geipele, I. (2015). Construction Management - Challenges, Influencing Factors and Importance of Investment Climate. In Proceedings of $5^{\text {th }}$ International Conference on Industrial Engineering and Operations Management (IEOM) (pp. 522-531). United Arab Emirates, Dubai, March 3-5, 2015. https://doi.org/10.1109/IEOM.2015.7093803

KfW Group. (2016a). KfW-Umweltprogramm [KfW Environmental Programm]. Retrieved from https://www.kfw.de/inlandsfoerderung/Unternehmen/Energie-

Umwelt/Finanzierungsangebote/Umweltprogramm-\%28240-241\%29/

KfW Group. (2016b). KfW Geschichte [History of KfW]. Retrieved from https://www.kfw.de/KfW-Group/About-KfW/Identit\%C3\%A4t/Geschichte-der-KfW/

Kḷavin̦šs, M., \& Zaloksnis, J. (2010). Vide un ilgtspejjigga attīstība [Environment and Sustainable Development]. Riga: LU Academic Publishing House, p. 334.

Krolkiewicz, H. J. (2016). Energieausweis: Zahlen - Daten - Fakten; Auswirkungen auf Vermietung, Verwaltung und Verkauf von Immobilien; rechtliche und technische Grundlagen [Energy proof: numbers - data - facts; Impact on the rental, management and sale of real estate; Legal and technical bases] Freiburg, Br.; München [i.e.] Planegg: Haufe-Gruppe. ISBN 978-3-648-04997-6.

Kuznets, S. (1955). Economic growth and income inequality. The American Economic Review, 45, 1-28. Retrieved from http://blog.bearing-consulting.com/wp-content/uploads/2012/09/ Economic.Growth.and_.Income.Inequality.pdf

Lexicon der Nachhaltigkeit [Lexicon of Sustainability]. (2015). Hans Carl von Carlowitz, 1713. Retrieved from https://www.nachhaltigkeit.info/artikel/hans_carl_von_carlowitz_1713_ 1393.htm

Lu, W., Peng, Y., Webster, C., \& Zuo, J. (2015). Stakeholders' willingness to pay for enhanced construction waste management: A Hong Kong study. Renewable and Sustainable Energy Reviews, 47, 233-240. http://dx.doi.org/10.1016/j.rser.2015.03.008

Manders, T., Chateau, J., Magné, B., Vuuren, D., Prins, A. G., \& Dellink, R. (2012). Socioeconomic Developments. OECD Environmental Outlook to 2050: The Consequences of Inaction (pp. 45-69). Paris: OECD Publishing. https://doi.org/10.1787/env outlook-2012-5-en

O’Daniel, B. (2012). Ökologisches Bauen. Arbeitsmarkt. Umweltschutz und Naturwissenschaften. Informationsdienst des Wissenschaftsladen Bonn. Jobmotor Nachhaltigkeit. Teil 3. Retrieved from http://www.wila-arbeitsmarkt.de/files/uws_2012_19_oekologisches_bauen.pdf

Pahl-Weber, E., Henckel, D., (Eds.). (2008). The Planning System and Planning Terms in Germany. A Glossary. Hanover: ARL. ISBN 978-3-88838-233-8, ISSN 1619-1986. Retrieved from http://shop.arl-net.de/media/direct/pdf/ssd_7.pdf

Pfnür, A. (2002). Modernes Immobilienmanagement: Facility-Management und Corporate-RealEstate-Management [Modern Real Estate Management: Facility Management and CorporateReal-Estate-Management]. Berlin: Springer. 342 p. https://doi.org/10.1007/978-3-662-08810-4

Ringel, M., Schlomann, B., Krail, M., \& Rohde, C. (2016). Towards a green economy in Germany? The role of energy efficiency policies. Applied Energy, 179, 1293-1303. https://doi.org/10.1016/j.apenergy.2016.03.063

Roy Choudhury, A. K. (2015). Development of Eco-Labels for Sustainable Textile. In S. S. Muthu (Ed.), Roadmap to Sustainable Textiles and Clothing. Regulatory Aspects and Sustainability Standards of Textiles and the Clothing Supply Chain (pp. 137-173). Singapore: Springer. https://doi.org/10.1007/978-981-287-164-0_6

Statistisches Bundesamt [Federal Office of Statistics]. (2016). Nachhaltigkeit [Sustainability]. Retrieved from https://www.destatis.de/DE/ZahlenFakten/GesamtwirtschaftUmwelt/Umwelt/ UmweltoekonomischeGesamtrechnungen/Nachhaltigkeit/Tabellen/Indikatoren.html

Štaube, T. (2013). Issues of Spatial Economic Allocation of the Entrepreneurial Activities in Latvia (Doctoral thesis, Riga Technical University). Riga: RTU Press, 191 p.

Štaube, T., Leemeijer, B., Geipele, S., Kauškale, L., Geipele, I., \& Jansen, J. (2016). Economic and Financial Rationale for Age-Friendly Housing. Journal of Financial Management of Property and Construction, 21(2), 99-121. https://doi.org/10.1108/JFMPC-05-2015-0015 
UNEP (United Nations Environment Programme). (2012). Geo5 Global Environmental Outlook. Environment for the future we want. Malta: Progress Press Ltd. Retrieved from http://web.unep.org/geo/sites/unep.org.geo/files/documents/geo5_report_c1.pdf

UNEP (United Nations Environment Programme). (2016). UNEP 2015 Annual Report. ISBN 978-92-807-3518-5. Retrieved from http://www.unep.org/annualreport/2015/en/index.html

USGBC (U.S. Green Building Council). (2014). Checklist: LEED v4 for Building Design and Construction. Retrieved from http://www.usgbc.org/resources/leed-v4-building-design-andconstruction-checklist

World Commission on Environment and Development. (1987). Our Common Future (Brudtland Report). Retrieved from http://www.un-documents.net/our-common-future.pdf

World Green Building Council. (2013). Business Case for Green Building reports. A review of the Costs and Benefits for Developers, Investors and Occupants. Retrieved from http://www.worldgbc.org/files/1513/6608/0674/Business_Case_For_Green_Building_Report_ WEB_2013-04-11.pdf

\section{AUTHORS' SHORT BIOGRAPHIES}

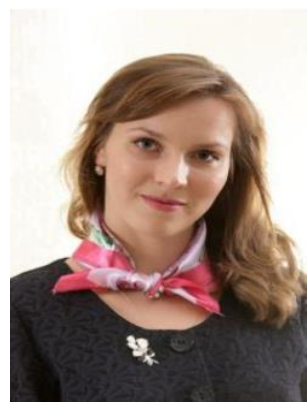

Linda Kauškale, Mg. oec., is a lecturer, a $\mathrm{PhD}$ student and an assistant researcher with the Institute of Civil Engineering and Real Estate Economics, Faculty of Engineering Economics and Management, Riga Technical University. She obtained Professional Master Degree with distinction in Civil Construction and Real Estate Management, has the qualification of Real Estate Economist and extensive practical experience. She has participated in international scientific conferences in Latvia, United Arab Emirates, Singapore, Malaysia, Lithuania etc. Her main research areas are real estate market and macroeconomic analysis, business cycle, sustainable construction, decision-making, environmental development, etc. She is a Professional Member of Industrial Engineering and Operations Management Society. She was a FIABCI scholar in autumn 2013. In 2016, she is Deutsche Bundesstiftung Umwelt (DBU) Scholarship holder.

ORCID iD: http://orcid.org/0000-0002-0280-2977

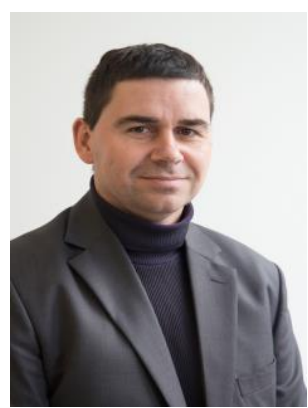

Professor Frank Riemenschneider, Dr., is Chair Holder of Facility Management in Fachhochschule Münster in Germany and the scientific director of Institute of Site and Facility Management GmbH, as well as of Institute of Waste, Wastewater and Infrastructure Management. He is an Associate Member of PPP Task Force Nordrhein-Westfalen, Associate Member of German Facility Management Association (GEFMA) and International Facility Management Association (IFMA). $\mathrm{He}$ is a representative of FH-Münster in European Facility Management Network EuroFM. He participated in a variety of projects in areas of facility management, site management, public private partnership and has wide practical experience. He has written many scientific publications, delivered lectures and workshops in the field of PPP and FM in Germany and abroad. His field of competence is a range of actual questions in site management and in public private partnership areas, including hybrid value creation, innovation management, entrepreneurship and facility management. Since 2014, he is a guest Professor at CUJAE, Havana, Cuba. 


\section{APPENDIX 1}

\section{Benefits for all - Green Building Benefits by DGNB System (DGNB System, 2016c)}

\begin{tabular}{|c|c|}
\hline Group & Benefits \\
\hline $\begin{array}{l}\text { The benefits for } \\
\text { users }\end{array}$ & $\begin{array}{l}\text { - Healthy users: The DGNB System takes the health and well-being of building } \\
\text { users into account and helps to reduce illness. } \\
\text { - Lower costs for users: The DGNB System focuses on the building's overall life } \\
\text { cycle from the outset, lowers costs and optimizes processes in operation. } \\
\text { Sustainable planning can thereby reduce ancillary costs in the long term. } \\
\text { - For future generations: DGNB certified buildings consume } \\
\text { fewer resources during construction, have lower greenhouse gas emissions and } \\
\text { largely can be recycled. In thus reducing waste, they make an active contribution } \\
\text { to protecting the environment. }\end{array}$ \\
\hline $\begin{array}{l}\text { Advantages for } \\
\text { building owners } \\
\text { and investors }\end{array}$ & $\begin{array}{l}\text { - Quality from the outset: As from the early planning stage, the DGNB Pre- } \\
\text { certificate reassures building owners } \\
\text { and users that the building will achieve its ultimate performance targets. } \\
\text { - } \text { Equal consideration for economic aspects: The economic } \\
\text { sustainability of a building is seen as being every bit as relevant as its } \\
\text { environmental, sociocultural and technical performance. } \\
\text { - Increased market opportunities: The DGNB Certificate increases a building's } \\
\text { sale and rental potential by providing owners and users with a clear indication of } \\
\text { its superior quality. } \\
\text { - Safeguarding further rentals: The ever-growing demand for certified buildings } \\
\text { minimizes the risk of vacancies. } \\
\text { - Simplifying funding: Properties likely to qualify for DGNB certification often } \\
\text { secure loans more quickly and at better conditions. } \\
\text { - International comparability: DGNB certified buildings are comparable at both } \\
\text { national and international levels. } \\
\text { - Precise assessment: Individual profiles based on the standardized DGNB }\end{array}$ \\
\hline $\begin{array}{l}\text { Advantages for } \\
\text { planners and } \\
\text { architects }\end{array}$ & $\begin{array}{l}\text { Promoting integrated planning: DGNB pre-certification in particular supports } \\
\text { integrated planning, providing early optimization potential for construction, } \\
\text { management, conversion and dismantling with an emphasis on optimizing costs. } \\
\text { This means that the focus of the project is on quality from the very beginning. } \\
\text { Targeted planning and monitoring: A systematic definition of sustainability } \\
\text { targets based on DGNB criteria raises all stakeholders' awareness at an early } \\
\text { stage and serves as a central instrument for quality assurance during the } \\
\text { construction phase. } \\
\text { Assessing overall performance: Rather than specifying individual measures, the } \\
\text { DGNB System sets targets for measuring a building's overall performance. In } \\
\text { doing so, it actively promotes innovative building concepts. }\end{array}$ \\
\hline $\begin{array}{l}\text { The benefits for } \\
\text { consultants and } \\
\text { product } \\
\text { manufacturers }\end{array}$ & $\begin{array}{l}\text { Clear innovation potential: For each of the relevant criteria, the DGNB System } \\
\text { shows consultants and manufacturers the extent to which building products } \\
\text { influence the sustainability of the project as a whole. In this way, products can } \\
\text { be further developed and optimized from a sustainability perspective. Here, too, } \\
\text { the focus is on the entire life cycle - and therefore on the long-term quality of } \\
\text { products used in construction. }\end{array}$ \\
\hline
\end{tabular}

